\title{
PCR-RFLP: a targeted method to reveal host specific malacosporean infection profiles (Cnidaria: Myxozoa: Malacosporea)
}

\author{
${\text { Paolo Ruggeri }{ }^{1, *}, \text { Juliana Naldoni }^{2}, \text { Hanna Hartikainen }}^{3}$, Beth Okamura ${ }^{1}$ \\ ${ }^{1}$ Natural History Museum, Cromwell Rd, Kensington, London SW7 5BD, UK \\ ${ }^{2}$ Departamento de Ecologia e Biologia Evolutiva, Universidade Federal de São Paulo, Rua Professor Artur Riedel, \\ no. 275, CEP 09972-270, Diadema, SP, Brazil \\ ${ }^{3}$ School of Life Sciences, University of Nottingham, University Park, Nottingham NG7 2RD, UK
}

\begin{abstract}
Malacosporeans are a group of endoparasitic cnidarians (Myxozoa) that use freshwater bryozoans and fish as final and intermediate hosts, respectively. The malacosporean Tetracapsuloides bryosalmonae causes proliferative kidney disease (PKD), an emerging disease in aquaculture and wild fish populations, including threatened salmonids in Europe and the USA. Mixed infections of malacosporeans are often encountered, and a monitoring tool for screening of multiple malacosporean species in either their fish or bryozoan hosts is therefore desirable. We describe an inexpensive method that combines PCR amplification of the partial 18S rRNA gene ( 260 bp) and a single-step restriction fragment length polymorphism (RFLP) method for identification of 10 malacosporean lineages and species. We demonstrate and test this methodology on a set of DNA extracted from malacosporeans infecting fish kidney and tissues sampled from bryozoan colonies and compare the results with Sanger sequencing of the same parasite DNA isolates. The PCR-RFLP and Sanger sequencing methods agreed in $100 \%$ of cases. The PCR-RFLP method offers a number of opportunities, including screening large panels of host tissue samples to gain insights into infection patterns, characterizing mixed infections, and confirming highly pathogenic $T$. bryosalmonae infections. The method can also be further refined as new sequence data become available for malacosporeans.
\end{abstract}

KEY WORDS: 18S rDNA · Restriction enzymes · Myxozoa · Buddenbrockia spp. · Tetracapsuloides spp. · Mixed infections

\section{INTRODUCTION}

Myxozoans comprise a diverse but poorly sampled clade of endoparasitic cnidarians. With some 2600 described species, they currently represent $19 \%$ of total cnidarian species diversity (Okamura et al. 2018). All have complex life cycles, exploiting invertebrate and vertebrate hosts (Lom \& Dyková 2006, Okamura et al. 2015). Myxozoans are divided into 2 major groups, the highly derived and species-rich Myxosporea and the species-poor Malacosporea characterized by the retention of primitive features

\footnotetext{
${ }^{*}$ Corresponding author: ruggeripaolo@inwind.it
}

(Gruhl \& Okamura 2015). So far, all evidence suggests that freshwater bryozoans (Phylum Bryozoa; Class Phylactolaemata) are the only invertebrate hosts used by malacosporeans, with sporogonic stages developing in the body cavity (Canning et al. 2000, Hartikainen et al. 2014, Patra et al. 2017). For many years, salmonids were the only fish hosts known to be exploited by malacosporeans, with the then unplaced parasite (referred to as 'PKX organism') being detected in kidney of fish suffering from proliferative kidney disease (PKD) (Hedrick et al. 1993). More recently, malacosporean infections have

(C) The authors 2020. Open Access under Creative Commons by Attribution Licence. Use, distribution and reproduction are unrestricted. Authors and original publication must be credited. 
been detected in kidney of fish belonging to a range of families (Cyprinidae, Percidae, Nemacheilidae) (Bartošová-Sojková et al. 2014, Naldoni et al. 2019).

The life cycles of some 50 myxozoan species have been fully resolved (Estzerbauer et al. 2015). For malacosporeans, fish hosts supporting transmission have been demonstrated for 3 species (Feist et al. 2001, Morris \& Adams, 2006a, Grabner \& El-Matbouli 2010). The only fully resolved malacosporean life cycle is that of Tetracapsuloides bryosalmonae, the causative agent of PKD (Feist et al. 2001, Morris \& Adams 2006a). PKD is an emerging disease (Okamura et al. 2011) that has been associated with declining wild salmonid populations and fish kills in e.g. Switzerland (Borsuk et al. 2006), Austria (Lewisch et al. 2018), Scandinavia (Sterud et al. 2007, Dash \& Vasemägi 2014, Vasemägi et al. 2017), Iceland (Kristmundsson et al. 2010) and the USA (MacConnell \& Peterson 1992, Opitz \& Rhoten 2017, Hutchins et al. 2019). PKD is also highly problematic in fish farms and hatcheries, with mortalities of up to $75 \%$ (Ferguson \& Needham 1978) and 95\% (Hedrick et al. 1984) being recorded. T. bryosalmonae is more broadly distributed in Europe than previously realized (e.g. Mo \& Jørgensen 2017). Recent outbreaks of PKD in wild fish populations are notably linked with increases in temperature (e.g. Sterud et al. 2007, Kristmundsson et al. 2010). The development of tools to specifically detect $T$. bryosalmonae infections in potential hosts is therefore important for assessing the risk of disease outbreak and the potential for disease mitigation (Jones et al. 2015) as our environment changes.

Recent molecular investigations have detected a range of malacosporean species infecting various fish and bryozoan hosts, with no clinical signs of disease in the former (Bartošová-Sojková et al. 2014, Hartikainen et al. 2014, Patra et al. 2017, Naldoni et al. 2019). These studies are expanding our understanding of malacosporean diversity and reveal a range of hosts potentially exploited in parasite life cycles. For example, T. bryosalmonae has been detected in whitefish (Sobociński et al. 2018, Naldoni et al. 2019) and other malacosporeans have variously been characterized in kidney of e.g. carp, roach, dace, stone loach and gudgeon (Bartošová-Sojková et al. 2014, Naldoni et al. 2019). Because disease is commonly exacerbated by environmental change, the ability to assess disease risk is of increasing interest, particularly since PKD is already known to be linked with warming waters. Screening for disease agents across a diversity of potential hosts would thus be desirable in order to address disease risk, biodiversity, and ecosystem sustainability in our changing world.

Identification of malacosporean infections currently relies on sequencing a diagnostic region of the 18S rRNA gene (Grabner \& El-Matbouli 2010), a relatively costly process when dealing with many samples. Furthermore, mixed infections are likely to occur, having been observed visually in bryozoans from some populations in regions sampled here (B. Okamura pers. obs.). Mixed infections have also been detected by molecular approaches (e.g. BartošováSojková et al. 2014). They are particularly difficult to distinguish using Sanger sequencing without cloning (Atkinson et al. 2015). Moreover, parasitic infections are not generally uniformly distributed in host populations, requiring the sampling of multiple host individuals. Profiling the malacosporean communities in a targeted fashion in large sets of putatively infected host samples is therefore necessary to investigate the ecological and evolutionary drivers of host-parasite dynamics in natural systems. The aim of this study was therefore to develop a rapid and relatively lowcost protocol for screening and identifying a large proportion of the currently known malacosporeans in both fish and invertebrate host material. We designed and tested the use of restriction enzyme fragment length polymorphisms (RFLPs) in amplified PCR products of $18 \mathrm{~S}$ rDNA for discriminating malacosporean species. This simple PCR-RFLP approach uses restriction endonucleases (restriction enzymes) to digest a PCR-amplified fragment of DNA (Vesterlund et al. 2014). The restriction enzymes specifically recognize nucleotide sequences of the DNA fragment where they effect cleavage. The cleavage is effective on short (few hundreds of bp) PCR products and could potentially be used to identify malacosporean infections in historical material preserved in museum or other archival collections (Harmon et al. 2019).

\section{MATERIALS AND METHODS}

\subsection{Development of malacosporean detection primers}

Primers Malsp 1F (5'-GGT AGA GTG AAA CTG CGG ATA GC-3') and Malsp 2R (5'-CTA ACW ACA AAT TGA TAG GGC G-3') were developed to amplify an approximately $260 \mathrm{bp}$ portion of the $18 \mathrm{~S}$ rRNA gene of malacosporeans. The primers were designed to be specific to malacosporeans, with broad compatibility across the Malacosporea priori- 
tized (contingent on the current representation of malacosporean sequences in GenBank). Through visual inspection of alignments comprising malacosporean, likely co-occurring myxosporean, and freshwater cnidarian sequences, primers were placed in a conserved section of the 18S rRNA gene. The targeted amplicon comprised a moderately variable area, facilitating species separation via RFLP analysis. The genomic region was primarily chosen to minimize false negative detections of malacosporeans (when using other existing malacosporean primers) and because the amplicon contained a moderate amount of variation flanked by longer highly conserved regions. We reasoned that use of the RFLP method could then identify most of the known species. However, we expected that a minority of cases would not be identified to species by the PCR-RFLP assay, in which case, primers targeting a longer amplicon would then be needed, coupled with Sanger sequencing. Candidate primers were designed using Primer3Plus v.2.4.2 (Untergasser et al. 2012) and evaluated manually and by using NetPrimer (Premier Biosoft). Primer pair sequences were subsequently checked against public databases to obtain an estimate of the potential for non-specific binding to other relevant targets.

The PCR reaction for Malsp 1F/2R was as follows: $3 \mu \mathrm{l}$ of forward and reverse primer mix $(5 \mu \mathrm{M}), 0.9 \mu \mathrm{l}$ dNTP (20 mM), $6 \mu$ l buffer (5×, Green GoTaq Flexi Buffer), $2.4 \mu \mathrm{l} \mathrm{MgCl} \mathrm{Mg}_{2}(25 \mathrm{mM}), 0.15 \mu \mathrm{l} \mathrm{GoTaq} \mathrm{(5} \mathrm{U}^{-1}$ G2 Flexi DNA Polymerase, Promega), $5 \mu$ of DNA template and molecular grade $\mathrm{H}_{2} \mathrm{O}$ to a total volume of $30 \mu \mathrm{l}$. The PCR conditions were: $5 \mathrm{~min}$ at $95^{\circ} \mathrm{C} ; 35$ cycles of $40 \mathrm{~s}$ at $95^{\circ} \mathrm{C}, 1 \mathrm{~min}$ at $55^{\circ} \mathrm{C}, 1 \mathrm{~min}$ at $72^{\circ} \mathrm{C}$. A final extension step was performed exposing amplicons at $72^{\circ} \mathrm{C}$ for $5 \mathrm{~min}$. PCR amplicons were visualized by running $5 \mu \mathrm{l}$ of PCR product on a $2 \%$ agarose gel with GelRed ${ }^{\circledR}$ Nucleic Acid Gel Stain (Biotium) for $45 \mathrm{~min}$.

\subsection{Development of endonuclease digestion protocols}

Virtual digestions were carried on FASTA sequences of all existing malacosporean sequences deposited in GenBank, including partial or full 18S rRNA gene sequences. The 112 sequences of the 18S rRNA gene that were retrieved from GenBank (www.ncbi.nlm.nih.gov/) ranged in length from 193 to $1794 \mathrm{bp}$. These sequences were representative of 5 species of Tetracapsuloides (T. bryosalmonae [Canning et al. 1999], T. vermiformis [Patra et al.
2017], Tetracapsuloides sp. A [Tetracapsuloides sp. 1 sensu Bartošová-Sojková et al. 2014], Tetracapsuloides sp. B [Tetracapsuloides sp. 4 sensu BartošováSojková et al. 2014], Tetracapsuloides sp. C [Tetracapsuloides sp. 5 sensu Bartošová-Sojková et al. 2014]), Malacosporea sp. A (which equates to Tetracapsuloides sp. 3 sensu Bartošová-Sojková et al. 2014), and 5 species of Buddenbrockia (B. allmani [Canning et al. 2007], B. bryozoides n. comb. [Patra et al. 2017], B. plumatellae [Schröder, 1910], Buddenbrockia sp. A [Buddenbrockia sp. 3 sensu Bartošová-Sojková et al. 2014], Buddenbrockia sp. B [Buddenbrockia sp. 2 sensu Bartošová-Sojková et al. 2014]). No 18S rRNA sequences were retrieved that wholly encompassed the region of interest for the species Buddenbrockia sp. C (Buddenbrockia sp. 1 sensu Hartikainen et al. 2014), Malacosporea sp. C (Tetracapsuloides sp. 2 sensu Bartošová-Sojková et al. 2014), Malacosporea sp. D (syn. B. plumatellae Cowan Lake, USA novel lineage sensu Evans et al. 2010), Malacosporea sp. E (syn. Malacosporean novel lineage 2 sensu Hartikainen et al. 2014) and Malacosporea sp. F (syn. lobey parasite or Malacosporean novel lineage 1 sensu Hartikainen et al. 2014). A maximum likelihood phylogenetic tree was redrawn from Fiala et al. (2015) in order to graphically show relations among the malacosporean species listed above (Fig. 1).

Of the 112 sequences examined, 49 were retained for virtual digestion, as they contained the region inferred to be amplified by the Malsp 1F/2R primers, with inferred amplicons varying between 253 and 259 bp (Fig. S1 and Table S1 in the Supplement at www.int-res.com/articles/suppl/d141p091_supp.pdf). The inferred amplicons were subsequently analyzed using the online software RestrictionMapper (http:// restrictionmapper.org/index.html). Restriction sites were then mapped on all of the malacosporean species for which the target amplicon sequence was known and endonucleases containing a maximum of 2 shearing sites were retained, giving a set of 7 potentially informative endonucleases (Fig. 1). These were: Xba I (Xanthomonas badrii, 5'..T/ CTAGA..3'; 20000 units $\mathrm{ml}^{-1}$ ), Nru I (Nocardia rubra, 5'..TCG/CGA...3'; 10000 units $\mathrm{ml}^{-1}$ ), Nde I (Neisseria denitrificans, 5'..CA/TATG..3'; 20000 units $\mathrm{ml}^{-1}$ ), Lwe I/Sfa NI (Streptococcus faecalis ND547, 5'..GCATC(N) $)_{5} / . .3$; 2000 units $\mathrm{ml}^{-1}$ ), Nsp I (Nostoc spp. C, 5'..RCATG/Y..3'; 10000 units $\mathrm{ml}^{-1}$ ), Afl II (Anabaena flos-aquae, 5'..C/TTAAG..3'; 20000 units $\mathrm{ml}^{-1}$ ), Eco57 I/Acu I (Acinetobacter calcoaceticus, $5^{\prime}$..GTGAAG(N) ${ }_{16} / . .3^{\prime}$; 5000 units $\mathrm{ml}^{-1}$ ) (New England Biolabs). 

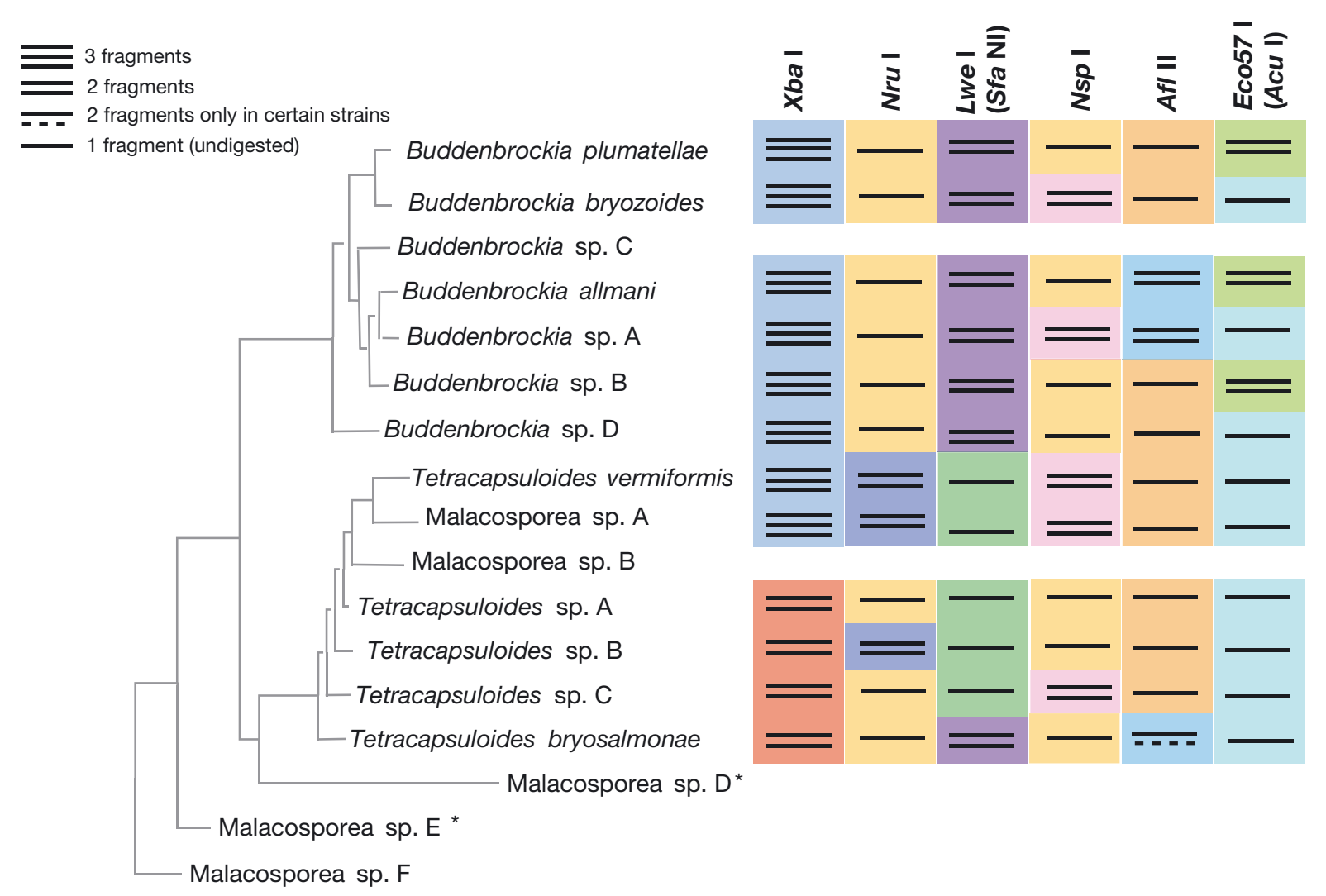

Fig. 1. Expected fragments produced after the PCR-RFLP procedure according to the 6 restriction enzymes employed (Xba I, Nru I, Lwe I/Sfa NI, Nsp I, Afl II and Eco57 I/Acu I). The phylogenetic tree was redrawn according to the malacosporean phylogeny published by Fiala et al. (2015). The bars signify the fragments resulting from PCR-RFLP for each taxon. The color scheme for each enzyme represents malacosporean taxa with identical restriction fragment patterns. ${ }^{*}$ Taxa for which a virtual digest was conducted using partial sequences (reported in Table S1)

The 7 endonucleases were then assayed individually by conducting enzyme digestions largely according to the manufacturer's protocols but with slight modifications (see Appendix). The final volume for each enzyme digestion was $15 \mu \mathrm{l}$ and comprised $7.5 \mu \mathrm{l}$ molecular grade $\mathrm{H}_{2} \mathrm{O}, 1.5 \mu \mathrm{l}$ enzyme buffer, $1 \mu \mathrm{l}$ restriction enzyme and $5 \mu \mathrm{l}$ DNA template (product generated by the primers Malsp 1F/2R) (see Appendix). The digestions were incubated individually for at least $15 \mathrm{~min}$ at $37^{\circ} \mathrm{C}$, then visualized by running $7 \mu \mathrm{l}$ of digestion product through a $2 \%$ agarose gel stained with GelRed® Nucleic Acid Gel Stain for $45 \mathrm{~min}$. The cutting patterns produced by the restriction enzymes were used to deduce species using a 'process-of-elimination' approach explained in Fig. 2.

\subsection{Validation and application of PCR-RFLP method}

To validate the species specificity of the RFLP patterns, 2 sets of samples with known, previously se- quenced malacosporean species were used. One set of 62 samples consisted of DNA extracted from malacosporean-infected fish kidney (Table S2) used by Naldoni et al. (2019), who employed 2 primer sets to detect malacosporean infections: mala-f and mala-r (Grabner \& El-Matbouli 2010) that amplify approximately 680 bp, and budd-f and budd-r (Grabner \& ElMatbouli 2010) that amplify approximately $1784 \mathrm{bp}$. Their analyses identified infections of 5 malacosporean species belonging to either Tetracapsuloides or Buddenbrockia in populations of 7 European fish species. Naldoni et al. (2019) conducted their work in the same laboratory using the same equipment as in our study. We re-amplified the 62 positive fish kidney DNA extracts developed by Naldoni et al. (2019) using our newly developed primers Malsp 1F/2R. The RFLP method was then applied on the PCR product and compared with the species identified by Sanger sequencing following use of the mala- $\mathrm{f} / \mathrm{r}$ and budd-f/r primers (see Table S3). To check for the occurrence of false positives produced by the Malsp 1F/2R primers, samples from 10 uninfected fish specimens and 10 


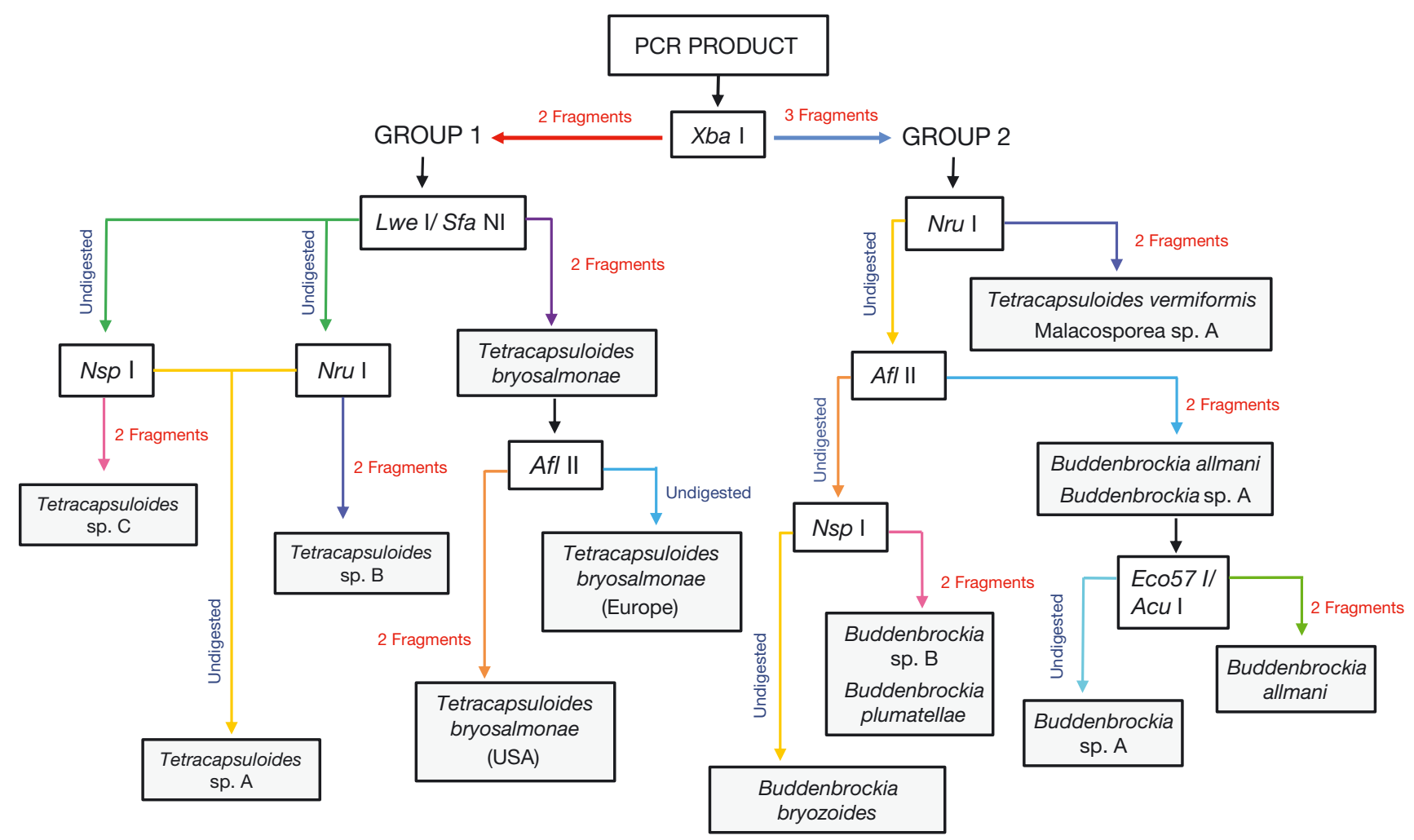

Fig. 2. Outline of the RFLP method using 6 restriction enzymes (in clear boxes). The PCR product (using the primers Malsp $1 \mathrm{~F} / 2 \mathrm{R}$ ) is first digested using the restriction enzyme Xba I to enable identification of isolates from Groups 1 or 2, depending on the number of fragments produced (red lettering). Use of further restriction enzymes determines species according to the number of further fragments produced (red lettering) or lack of further digestion (blue lettering)

uninfected colonies of Fredericella sultana (see below) were co-amplified with the positive samples used by Naldoni et al. (2019).

DNA extracted from 382 colonies of the freshwater bryozoan $F$. sultana from various sites in the UK (Table S2) provided material to further explore the performance of the PCR-RFLP approach. These colonies had been screened using a stereomicroscope and dissection to assess overt infection status (presence of $T$. bryosalmonae sacs; Tops et al. 2006). Such screening does not identify covert infection which involves tiny isolated stages (single cells and small groups of cells) that develop in association with the body wall (Morris \& Adams 2006b, Canning et al. 2008). Covert infections can be detected by PCR, and extensive monitoring of UK bryozoan populations indicates that covert infections are often present in at least $50 \%$ of $F$. sultana colonies across time and space (Fontes et al. 2017). DNA was extracted using a HotSHOT protocol (Truett et al. 2000) and was used as template for PCR of malacosporean infections using the primers Malsp 1F/2R. We then examined material identified to be infected by restriction enzyme digestion. Sanger sequencing was conducted on 30 colonies of the bryozoan $F$. sultana using the Malsp 1F/2R primers. We also included DNA previously extracted from 2 infected colonies of Lophopus crystallinus available as stored material. All PCR products were used as template to perform digestions with the selected restriction enzymes using 1 endonuclease per reaction.

\section{RESULTS AND DISCUSSION}

\subsection{Assessing the performance of primers Malsp 1F/2R}

The primers Malsp 1F/2R confirmed infection in $100 \%$ of the fish DNA extracts that Naldoni et al. (2019) identified and characterized using the primers mala-f/r and budd-f/r (Table S3). None of the uninfected fish DNA produced an amplified fragment. These results suggest that the Malsp 1F/2R primers are at least as consistent as primers previously developed for malacosporean detection. 


\subsection{Restriction enzyme selection and cleavage patterns}

Nde I was eliminated from the 7 restriction enzymes initially selected for potential diagnosis of myxosporean infections (Table S1) because both Nde I and Lwe I/Sfa NI discriminate Tetracapsuloides bryosalmonae from the other Tetracapsuloides species. We note, however, that Nde I is able to discriminate some strains of $T$. bryosalmonae (Table S1) producing a cut for strains KF731712 (from Stirling, Scotland, UK), FJ981823 (from River Cerne, UK), KJ150287 (from River Wheeler, UK), KJ150282 (from River Juine, France) and AJ937885 (from Lombardia, Italy). However, because these strains were not clearly associated with specific hosts (either Salmo trutta or Oncorhynchus mykiss), or geographic locations, they have not been further targeted here.

The PCR-RFLP is a 'process-of-elimination' method that uses 6 diagnostic restriction enzymes to digest the PCR-amplified product of primers Malsp 1F/2R. The procedure follows single nucleotide substitutions in a portion of the 18S rRNA gene (as shown in Fig. S1) that were identified to be informative of species-level differences across the malacosporean molecular phylogeny (Fiala et al. 2015; their Fig. 1). For 10 malacosporean species the diagnostic restriction enzymes provided a unique RFLP pattern. The PCR-RFLP method involves splitting a single positive PCR reaction into 6 separate restriction reactions, which are all run in parallel, followed by a stepwise analysis of resulting banding patterns (Figs. 1 \& 2).

The first step uses $\mathrm{Xba}$ I to sort malacosporean species into 2 distinct groups. Group 1 includes T. bryosalmonae, Tetracapsuloides sp. A, Tetracapsuloides sp. B and Tetracapsuloides sp. C, these being identified by digestion that produces 2 fragments $(\sim 180$ and $80 \mathrm{bp}$ ). Group 2 includes Buddenbrockia bryozoides, B. plumatellae, Buddenbrockia sp. A, Buddenbrockia sp. B and T. vermiformis/Malacosporea sp. A. Digestion of taxa in Group 2 produces 3 fragments $(\sim 110,80$ and 70 bp) (Figs. 1 \& S1). In $100 \%$ of cases, restriction enzyme digestions of infected fish and bryozoans discriminated between these groups in accordance with results from Sanger sequencing.

Further steps employ restriction enzymes to discriminate taxa within each group. Lwe I/Sfa NI is used to digest taxa in Group 1 and Nru I for taxa in Group 2. Lwe I/Sfa NI digestion produces 2 fragments $(\sim 140$ and $120 \mathrm{bp})$ if the species is T. bryosalmonae (Figs. 1 \& S1). This enzyme diagnosed all cases of both $T$. bryosalmonae-infected fish kidney (Naldoni et al. 2019) and bryozoan material (this study) in accord with Sanger sequencing. Subsequent use of Afl II distinguishes T. bryosalmonae strains from the USA (producing 2 fragments of $\sim 160$ and $100 \mathrm{bp}$ ) and T. bryosalmonae strains from Europe (which are not cut by this enzyme). Nru I digestion produces 2 fragments $(\sim 160$ and $100 \mathrm{bp})$ for 2 taxa: $T$. vermiformis and Malacosporea sp. A (Figs. $1 \& \mathrm{~S} 1$ ). These 2 taxa cannot be separated based on the PCRRFLP restriction patterns. There was 1 case where our PCR-RFLP screens of bryozoan colonies identified infection by $T$. vermiformis/Malacosporea sp. A. However, we cannot confirm this detection as Sanger sequencing attempts were not successful and cloning was not conducted.

Other restriction enzymes enable identification of known species within Group 1. Digestion by both Nsp I and Nru I produces fragments of $\sim 150$ and $110 \mathrm{bp}$ and the associated shearing sites are exclusive for Tetracapsuloides sp. C and Tetracapsuloides sp. B, respectively (Figs. $1 \& \mathrm{~S} 1$ ). When the 2 enzymes do not cause cleavage, the intact PCR product then identifies Tetracapsuloides sp. A. The use of enzymes Nsp I and Nru I identified 7 cases of gudgeon kidney infected by Tetracapsuloides sp. C and 1 case of common roach kidney infected by Tetracapsuloides sp. B. Sanger sequencing had previously identified this material (Naldoni et al. 2019), thus confirming the expected pattern outlined in our PCR-RFLP method.

The restriction enzyme Afl II can be used for further identification of taxa in Group 2. Afl II is predicted to recognize a shearing site in the 18S rRNA gene in 2 Buddenbrockia species (Buddenbrockia sp. A and B. allmani), producing 2 fragments ( 160 and $100 \mathrm{bp}$ ) (Figs. 1 \& S1). We had no direct proof of the ability of Afl II to diagnose Buddenbrockia sp. A because none of the fish and bryozoan samples were infected by this malacosporean species. However, this enzyme gave the expected digest results in $B$. allmani samples. Afl II digestion produced no fragments for the 62 fish kidney samples, nor for the 20 infected Fredericella sultana colonies, in keeping with specificity for recognizing Buddenbrockia sp. A and $B$. allmani as predicted by virtual digestions. The subsequent use of the enzyme Eco57 I/Acu I discriminates between Buddenbrockia sp. A and B. allmani, producing 2 fragments ( 150 and $110 \mathrm{bp}$ ) for $B$. allmani and leaving the Malsp 1F/2R PCR product of Buddenbrockia sp. A intact (Figs. 1 \& S1).

Finally, Nsp I applies when Group 2 malacosporeans are not digested by $\mathrm{Nru}$ I and Afl II. This enzyme recognizes a shearing site in the rRNA gene unique to $B$. bryozoides n. comb. producing 2 fragments of $\sim 150$ and 110 bp (Figs. 1 \& S1). A lack of digested product 
by Nsp I identifies the species complex B. plumatellae/Buddenbrockia sp. B. Nsp I correctly identified $B$. bryozoides n. comb. and B. plumatellae/Buddenbrockia sp. B in 16 infected fish kidneys identified as infected with Buddenbrockia sp. B and 8 fish kidneys infected with $B$. plumatellae according to Sanger sequencing. This result further establishes the use of $F$. sultana as a bryozoan host of Buddenbrockia sp. B, as previously reported by Hartikainen et al. (2014).

\subsection{Validation and application of the PCR-RFLP method on fish and bryozoan samples}

The identification of malacosporean species infecting fish kidneys by PCR-RFLP was consistent with their earlier identification by Sanger sequencing (Naldoni et al. 2019) (see Table S3). However, Sanger sequencing was required when PCR-RFLP was unable to distinguish between $B$. plumatellae and Buddenbrockia sp. B in order to confirm which taxon was present (Table 1). None of the 10 uninfected fish, nor the bryozoans provided evidence for false positives. This provides evidence that our method is highly consistent with Sanger sequencing in detecting and identifying malacosporean species for which we have current evidence (Table 1). Restriction enzyme digestion of the DNA extracted from 384 bryozoan tissue samples was consistent with amplification using the Malsp $1 \mathrm{~F} / 2 \mathrm{R}$ primers. The latter revealed infections in 122 samples while restriction enzyme digestion identified malacosporean infections and provided RFLP profiles in 118 cases. Four of the 122 cases failed to provide RFLP profiles appearing as smears during the electrophoresis suggesting agreement in parasite detection was high but imperfect (possibly due to false positives). Subsequent Sanger sequencing of a subset of this positive material (Table 2) was consistent in the identification of the 24 single infections revealed by PCR-RFLP analyses (Table 2) with the exception of 2 cases (CHT-32 and FCC-8), where Sanger sequencing failed. Because our identifications inferred by PCRRFLP were invariably consistent with all previous and independent identifications of material, we suggest that PCR errors (i.e. change in nucleotide composition due to DNA polymerase errors) are minimal and can effectively be discounted.

Our results also demonstrate that the Malsp 1F/2R primers can confirm covert infections in bryozoan samples. Covert infection dynamics appear to entail long-term persistence within bryozoan hosts (Fontes et al. 2017). When conditions are permissive for the development of overt infection, tiny isolated covert stages multiply and then develop into visible sacs causing overt infection (Morris \& Adams 2006b) that are relatively short-lived in the field (weeks; Tops 2004, Tops et al. 2009, Fontes et al. 2017). Overt infection development is extremely rapid (e.g. within $3 \mathrm{~d}$ in colonies collected from the field and main-

Table 1. Identification of malacosporean taxa according to Sanger sequencing (Sanger ID) and our described PCR-RFLP method (PCR-RFLP ID) infecting fish (see Table S2 for fish families) collected in localities in the UK, Switzerland and USA. Nomenclature of undescribed malacosporeans according to Fiala et al. (2015). n: number of fish sampled

\begin{tabular}{|c|c|c|c|}
\hline Fish host $[\mathrm{n}]$ & Location & Sanger ID & PCR-RFLP ID \\
\hline Brown trout Salmo trutta [6] & River Stour (UK) & $\begin{array}{c}\text { Tetracapsuloides } \\
\text { bryosalmonae }\end{array}$ & T. bryosalmonae \\
\hline $\begin{array}{l}\text { Rainbow trout Onco- } \\
\text { rhynchus mykiss [4] }\end{array}$ & River Furtbach (Switzerland) & T. bryosalmonae & T. bryosalmonae \\
\hline Brown trout $S$. trutta [16] & River Brubach (Switzerland) & T. bryosalmonae & T. bryosalmonae \\
\hline Brown trout $S$. trutta [1] & River Stour (UK) & T. bryosalmonae & T. bryosalmonae \\
\hline $\begin{array}{l}\text { Mountain whitefish Proso- } \\
\text { pium williamsoni [1] }\end{array}$ & Yellowstone River (USA) & T. bryosalmonae & T. bryosalmonae \\
\hline Rainbow trout O. mykiss [2] & Yellowstone River (USA) & T. bryosalmonae & T. bryosalmonae \\
\hline Gudgeon Gobio gobio [6] & River Stour (UK) & Tetracapsuloides sp. C & Tetracapsuloides sp. C \\
\hline Gudgeon G. gobio [1] & River Stour (UK) & Tetracapsuloides sp. C & Tetracapsuloides sp. C \\
\hline $\begin{array}{l}\text { Common roach Rutilus } \\
\text { rutilus [1] }\end{array}$ & River Stour (UK) & Tetracapsuloides sp. B & Tetracapsuloides sp. B \\
\hline $\begin{array}{l}\text { Stone loach Barbatula } \\
\text { barbatula [7] }\end{array}$ & River Stour (UK) & Buddenbrockia sp. B & $\begin{array}{l}\text { B. plumatellae/ } \\
\text { Buddenbrockia sp. B }\end{array}$ \\
\hline Stone loach B. barbatula [9] & River Stour (UK) & Buddenbrockia sp. B & B. plumatellae/ Buddenbrockia sp. B \\
\hline Common roach $R$. rutilus [7] & Blickling Lake (UK) & B. plumatellae & B. plumatellae/ Buddenbrockia sp. B \\
\hline $\begin{array}{l}\text { Common dace Leuciscus } \\
\text { leuciscus [1] }\end{array}$ & River Stour (UK) & B. plumatellae & B. plumatellae/ Buddenbrockia sp. B \\
\hline
\end{tabular}


Table 2. Identification of malacosporean taxa according to Sanger sequencing (Sanger ID) and our described PCR-RFLP method (PCR-RFLP ID) in 32 infected bryozoan colonies (and code of the bryozoan sample used) collected in localities in the UK. The percentage identity of our Sanger sequences with the representative sequence in GenBank is provided. Evidence for multiple infections identified by the PCR-RFLP method are indicated in bold. Fs: Fredericella sultana; LC: Lophopus crystallinus. Nomenclature of undescribed malacosporeans according to Fiala et al. (2015). Tb: Tetracapsuloides bryosalmonae; T. sp. A: Tetracapsuloides sp. A; Tv: T. vermiformis; Bp: Buddenbrockia plumatellae; B. sp. A: Buddenbrockia sp. A; B. sp. B: Buddenbrockia sp. B; Ba: B. allmani; na: not applicable

\begin{tabular}{|c|c|c|c|}
\hline $\begin{array}{l}\text { Bryozoan } \\
\text { (code) }\end{array}$ & Location & Sanger ID & PCR-RFLP ID \\
\hline Fs (RBW-4) & River Blackwater (Norfolk) & na & $T b ; T$. sp. A; Bp/B. sp. B; B. sp. A \\
\hline Fs (RBW-33) & River Blackwater (Norfolk) & na & $T b ; T$. sp. A; Bp/B. sp. B \\
\hline Fs (RTH-32) & River Thet (Norfolk) & B. sp. B (99.06\%; KJ150268.1) & $B p / B$. sp. B \\
\hline Fs (RTH-35) & River Thet (Norfolk) & B. sp. B (99.54\%; MT010122.1) & $B p / B$. sp. B \\
\hline$F_{S}(\mathrm{STI}-4)$ & River Stiffkey (Norfolk) & $T b(97.07 \% ;$ AJ937887.1) & $\mathrm{Tb}$ \\
\hline Fs (STI-14) & River Stiffkey (Norfolk) & B. sp. B (99.06\%; MT010122.1) & $B p / B$. sp. B \\
\hline Fs (STI-29) & River Stiffkey (Norfolk) & na & T. sp. A; Bp/B. sp. B \\
\hline Fs (STI-35) & River Stiffkey (Norfolk) & Tb (100\%; МT002366.1) & $T b$ \\
\hline Fs (STI-38) & River Stiffkey (Norfolk) & $T b(98.57 \% ; K F 731712.1)$ & $T b$ \\
\hline Fs (SBK-14) & Scarrow Beck (Norfolk) & Tb (98.05\%; МT002366.1) & $T b$ \\
\hline Fs (SBK-19) & Scarrow Beck (Norfolk) & $T b(98.00 \% ;$ EU570235.1) & $T b$ \\
\hline$F_{S}(\mathrm{SBK}-28)$ & Scarrow Beck (Norfolk) & $\mathrm{Tb}(95.59 \% ;$ МT002366.1) & $T b$ \\
\hline Fs (GLA-17) & River Glaven (Norfolk) & $T b(99.51 \%$; MG775223.1) & $T b$ \\
\hline Fs (CHT-12) & River Chet (Norfolk) & B. sp. B (99.01 \%; KJ150270.1) & $B p / B$. sp. B \\
\hline Fs (CHT-32) & River Chet (Norfolk) & na & TV/Malacosporea sp. A \\
\hline FS (NAR-7) & River Nar (Norfolk) & Tb (98.17\%; МТ002367.1) & $T b$ \\
\hline FS (NAR-10) & River Nar (Norfolk) & $T b(99.52 \% ; \mathrm{KJ} 150287.1)$ & $T b$ \\
\hline FS (NAR-12) & River Nar (Norfolk) & Tb (99.04\%; MT002367.1) & $T b$ \\
\hline Fs (NAR-14) & River Nar (Norfolk) & na & $\begin{array}{l}\text { Tv/Malacosporea sp. A; } \\
\text { T. sp. A; Bp/B. sp. B }\end{array}$ \\
\hline Fs (NAR-23) & River Nar (Norfolk) & na & $\begin{array}{l}\text { TV/Malacosporea sp. A; } \\
\text { T. sp. A; Bp/B. sp. B }\end{array}$ \\
\hline FS (WEN-8) & River Wensum (Norfolk) & B. sp. B (99.53\%; KJ150268.1) & $B p / B$. sp. B \\
\hline FS $(\mathrm{WEN}-16)$ & River Wensum (Norfolk) & B. sp. B (99.53\%; KJ150268.1) & $B p / B$. sp. B \\
\hline FS (RCO-16) & River Cocker (Cumbria) & B. sp. B (96.34\%; МТ010122.1) & $B p / B$. sp. B \\
\hline FS (RDW-19) & River Derwent (Cumbria) & B. sp. B (94.33\%; MT010122.1) & $B p / B$. sp. B \\
\hline FS (LUW-11) & Luggie Water (North Lanarkshire) & B. sp. B (100\%; MT010122.1) & $B p / B$. sp. B \\
\hline Fs (CRN-33) & River Carron (Stirlingshire) & B. sp. B (99.53\%; KJ150268.1) & $B p / B$. sp. B \\
\hline Fs (CRN-39) & River Carron (Stirlingshire) & na & $\begin{array}{l}\text { Tv/Malacosporea sp. A; } \\
\text { T. sp. A; Bp/B. sp. B }\end{array}$ \\
\hline FS (FCC-8) & Forth Clyde Canal (North Lanarkshire) & na & $B p / B$. sp. B \\
\hline Fs (PBK-8) & Park Beck (Cumbria) & T. sp. A (95\%; KJ150278.1) & T. sp. A \\
\hline Fs (PBK-23) & Park Beck (Cumbria) & $\mathrm{Tb}(98.57 \%$; MT002366.1) & $T b$ \\
\hline$L C(\inf 1)$ & Barton Blow Wells (Lincolnshire) & Ва (99.15\%; KJ150260.1) & $B a$ \\
\hline$L C(\inf 2)$ & Barton Blow Wells (Lincolnshire) & Ва (99.01\%; KJ150260.1) & $B a$ \\
\hline
\end{tabular}

tained in laboratory culture; Canning \& Okamura 2004). This collective information along with amplification of parasite DNA in some $31 \%$ (118 of 382) of field-collected colonies indicates that our primers are able to identify infections even when parasite DNA concentrations are likely to have been very low in many samples. Because covert infections are persistent over space and time (Fontes et al. 2017), while overt infections are transient (Tops et al. 2006), the ability to detect covert infections is of particular importance. Further examination of a range of material will help to reveal how sensitive the approach may be.
Six colonies of $F$. sultana were identified to have co-infections by PCR-RFLP analysis (Table 2). There was 1 case of infection by 2 malacosporean species (FS [STI-29]), 4 cases of infection by 3 malacosporeans (FS [RBW-33], Fs [NAR-14], FS [NAR-23], FS [CRN-39]), and 1 case of infection by 4 malacosporeans (Fs [RBW-4]) (Table 2). The chromatograms generated in Sanger sequencing of this material were composed of multiple overlapping peaks suggesting the presence of various exogenous DNA copies from different malacosporean species, as expected. These Sanger sequencing results highlight the advantage of PCR-RFLP in unambiguously detecting mixed 
infections. We suggest that when mixed infections are of interest, the accuracy of identifying mixed infections should be addressed through targeted cloning and sequencing before applying this method to large sample sets.

\subsection{Opportunities and constraints of the PCR-RFLP method}

Here we provide evidence for a simple, accurate and relatively rapid method to detect and identify currently known malacosporeans based on PCR amplification of a short portion of the malacosporean 18S rRNA gene and subsequent cleavage of the PCR product with a set of 6 enzymes that target speciesspecific restriction sites. The method is relatively inexpensive, and the high specificity of restriction enzymes for their cleavage sites enables both species identification and the ability to distinguish and characterize mixed infections. The PCR-RFLP methodology allows any laboratory with basic molecular biology facilities (i.e. thermal cycler and electrophoresis chambers) to screen biological samples using parallel enzyme digestions to gain species level information on malacosporean infections in less than $4 \mathrm{~h}$. It offers the additional and distinct advantage of being able to identify mixed infections without cloning and sequencing.

We predict that the method may prove useful for analyzing old samples and degraded DNA material due to the short length of the targeted portion of the $18 \mathrm{~S}$ rRNA gene. The method could also enable simultaneously screening large panels of potential vertebrate and invertebrate host tissue samples collected over space and time to gain rapid insights into infection patterns. The method may prove to be useful in analyses of environmental DNA (eDNA), although this would require extensive trialing in view of the complexity of eDNA samples and associated uncertainties regarding procedural reliability. Finally, it should be stressed that the method performs well in distinguishing $T$. bryosalmonae infections and hence offers an inexpensive means of screening for a parasite of particular concern.

The method does, however, have some constraints. For example, it is based exclusively on malacosporean species previously described and already characterized. It is also unable to discriminate between $T$. vermiformis and Malacosporea sp. A and between B. plumatellae and Buddenbrockia sp. B. In these specific cases, sequencing or targeting other amplicons will be needed for species discrimination.
A further constraint is the lack of full sequence data in GenBank for Buddenbrockia sp. C, Malacosporea sp. B, Malacosporea sp. D, Malacosporea sp. E and Malacosporea sp. F which covers the particular region of 18S rRNA sequence targeted by the Malsp $1 F / 2 R$ primers. It is therefore possible that the PCRRFLP method will not discriminate these malacosporean species. However, partial sequence data for Malacosporea sp. D and Malacosporea sp. E (Table S1) enabled testing the 6 endonucleases via virtual digestion. The missing part of the sequence was replaced with the sequence of the most closely related species for a conservative test. Results suggest that the method should discriminate the 2 taxa, but this should be further investigated when full sequence data or samples become available. The discovery of new malacosporean species may of course also complicate interpretations if they are not distinguished by the current set of enzymes. Nevertheless, the method is at present robust in the identification of a number of currently known malacosporean taxa (particularly those encountered in Europe), and includes the identification of $T$. bryosalmonae and mixed infections. When identification is ambiguous sequencing can then be adopted. Furthermore, refinement of the method can be explored if and when new malacosporean species become important to distinguish.

\subsection{Conclusion}

Our PCR-RFLP method provides an opportunity to easily detect and identify those malacosporean lineages and species currently identified in Europe. It also provides a means of detecting the highly pathogenic $T$. bryosalmonae in both Europe and North America. The approach can enable easy and quick screening for malacosporean infection prevalences and patterns of mixed infections because it offers an efficient means of simultaneously screening large panels of samples that may be collected across time or space. It may also enhance our understanding of the range of fish and bryozoan hosts used by malacosporeans as well as environmental factors that may influence malacosporean distributions and abundances. Future studies specifically addressing the efficiency of PCR-based methods could evaluate the performance of other enzymes and targeting of other genetic regions. Meanwhile, the PCR-RFLP assay can be updated or supplemented when new GenBank data for other malacosporean species become available. 
Acknowledgements. This research was conducted as part of the multi-institute Hydroscape research program supported by the National Environment Research Council (NERC) (NE/N005902/1). J.N. was supported by the scholarship no. 2016/08831-7 awarded by the São Paulo Research Foundation (FAPESP). H.H. was supported by Marie Curie Fellowship FP7-PEOPLE-2009-IEF-252159. This project benefitted variously from advice in identifying sites and help with sampling, most especially from Peter Hammond, Nigel Willby, Carl Sayer, Ambroise Baker, Alan Law, Tara Thrupp, Zarah Pattison, Geoff Phillips, Neil Rose, Simon Turner, Stephen Maberley, Mitzi de Ville, Ben Surridge, Tim Grapes, Ashlie Hartigan, Andrea Kelly and Jo-Anne Pitt. We are grateful to landowners, The Broads Authority, Natural England and Norfolk Wildlife Trust for access to collecting sites. We thank Patrick Hutchins and Adam Sepulveda for supplying Tetracapsuloides bryosalmonae DNA from Montana. Comments from 2 reviewers greatly helped us to improve the manuscript.

\section{LITERATURE CITED}

Atkinson SD, Bartošová-Sojková P, Whipps CM, Bartholomew JL (2015) Approaches for characterizing myxozoan species. In: Okamura B, Gruhl A, Bartholomew JL (eds) Myxozoan evolution, ecology and development. Springer International Publishing, Cham, p 111-123

Bartošová-Sojková P, Hrabcová M, Pecková H, Patra S and others (2014) Hidden diversity and evolutionary trends in malacosporean parasites (Cnidaria: Myxozoa) identified using molecular phylogenetics. Int J Parasitol 44:565-577

Borsuk ME, Reichert P, Peter A, Schager E, Burkhardt-Holm $\mathrm{P}$ (2006) Assessing the decline of brown trout (Salmo trutta) in Swiss rivers using a Bayesian probability network. Ecol Modell 192:224-244

Canning EU, Okamura B (2004) Biodiversity and evolution of the Myxozoa. Adv Parasitol 56:43-131

Canning EU, Curry A, Feist S, Longshaw M, Okamura B (2000) A new class and order of myxozoans to accommodate parasites of bryozoans with ultrastructural observations on Tetracapsula bryosalmonae (PKX Organism). J Eukaryot Microbiol 47:456-468

Canning EU, Curry A, Hill SL, Okamura B (2007) Ultrastructure of Buddenbrockia allmani n. sp. (Myxozoa, Malacosporea), a parasite of Lophopus crystallinus (Bryozoa, Phylactolaemata). J Eukaryot Microbiol 54:247-262

Canning EU, Curry A, Okamura B (2008) Early development of the myxozoan Buddenbrockia plumatellae in the bryozoans Hyalinella punctata and Plumatella fungosa, with comments on taxonomy and systematics of the Myxozoa. Folia Parasitol 55:241-255

Dash M, Vasemägi A (2014) Proliferative kidney disease (PKD) agent Tetracapsuloides bryosalmonae in brown trout populations in Estonia. Dis Aquat Org 109:139-148

Estzerbauer E, Atkinson S, Diamant A, Morris D, El-Matbouli M, Hartikainen H (2015) Myxozoan life cycles: practical approaches and insights. In: Okamura B, Gruhl A, Bartholomew JL (eds) Myxozoan evolution, ecology and development. Springer International Publishing, Cham, p 175-198

Evans NM, Holder MT, Barbeitos MS, Okamura B, Cartwright P (2010) The phylogenetic position of Myxozoa: exploring conflicting signals in phylogenomic and ribosomal data sets. Mol Biol Evol 27:2733-2746
Feist SW, Longshaw M, Canning EU, Okamura B (2001) Induction of proliferative kidney disease (PKD) in rainbow trout Oncorhynchus mykiss via the bryozoan Fredericella sultana infected with Tetracapsula bryosalmonae. Dis Aquat Org 45:61-68

Ferguson HW, Needham EA (1978) Proliferative kidney disease in rainbow trout Salmo gairdneri Richardson. J Fish Dis 1:91-108

Fiala I, Bartošová-Sojková P, Okamura B, Hartikainen H (2015) Adaptive radiation and evolution within the Myxozoa. In: Okamura B, Gruhl A, Bartholomew JL (eds) Myxozoan evolution, ecology and development. Springer International Publishing, Cham, p 69-84

Fontes I, Hartikainen H, Williams C, Okamura B (2017) Persistence, impacts and environmental drivers of covert infections in invertebrate hosts. Parasit Vectors 10:542

Grabner DS, El-Matbouli M (2010) Experimental transmission of malacosporean parasites from bryozoans to common carp (Cyprinus carpio) and minnow (Phoxinus phoxinus). Parasitology 137:629-639

Gruhl A, Okamura B (2015) Tissue characteristics and development in Myxozoa. In: Okamura B, Gruhl A, Bartholomew JL (eds) Myxozoan evolution, ecology and development. Springer International Publishing, Cham, p 155-174

* Harmon A, Littlewood DT, Wood CL (2019) Parasites lost: using natural history collections to track disease change across deep time. Front Ecol Environ 17:157-176

* Hartikainen H, Gruhl A, Okamura B (2014) Diversification and repeated morphological transitions in endoparasitic cnidarians (Myxozoa: Malacosporea). Mol Phylogenet Evol 76:261-269

Hedrick RP, Kent ML, Rosemark R, Manzer D (1984) Occurrence of proliferative kidney disease (PKD) among Pacific salmon and steelhead trout. Bull Eur Assoc Fish Pathol 4:34-37

*Hedrick RP, MacConnell E, de Kinkelin P (1993) Proliferative kidney disease of salmonid fish. Annu Rev Fish Dis 3:277-290

Hutchins PR, Sepulveda AJ, Hopper LR, Staigmiller KD (2019) The Yellowstone River fish-kill: Fish health informs and is informed by vital signs monitoring. Yellowstone Science 27:55-57

Jones SRM, Bartholomew JL, Zhang JY (2015) Mitigating myxozoan disease impacts on wild fish populations. In: Okamura B, Gruhl A, Bartholomew JL (eds) Myxozoan evolution, ecology and development. Springer International Publishing, Cham, p 397-413

Kristmundsson A, Antonsson T, Arnason E (2010) First record of proliferative kidney disease in Iceland. Bull Eur Assoc Fish Pathol 30:35-40

* Lewisch E, Unfer G, Pinter K, Bechter T, El-Matbouli M (2018) Distribution and prevalence of T. bryosalmonae in Austria: a first survey of trout from rivers with a shrinking population. J Fish Dis 41:1549-1557

*Lom J, Dyková I (2006) Myxozoan genera: definition and notes on taxonomy, life cycle terminology and pathogenic species. Folia Parasitol 53:1-36

* MacConnell E, Peterson JE (1992) Proliferative kidney disease in feral cutthroat trout from a remote Montana reservoir: a first case. J Aquat Anim Health 4:182-187

Mo TA, Jørgensen A (2017) A survey of the distribution of the PKD-parasite Tetracapsuloides bryosalmonae (Cnidaria: Myxozoa: Malacosporea) in salmonids in Norwe- 
gian rivers - additional information gleaned from formerly collected fish. J Fish Dis 40:621-627

Morris DJ, Adams A (2006a) Transmission of Tetracapsuloides bryosalmonae (Myxozoa: Malacosporea), the causative organism of salmonid proliferative kidney disease, to the freshwater bryozoan Fredericella sultana. Parasitology 133:701-709

Morris DJ, Adams A (2006b) Proliferative, presaccular stages of Tetracapsuloides bryosalmonae (Myxozoa: Malacosporea) within the invertebrate host Fredericella sultana (Bryozoan: Phylactolaemata). J Parasitol 92:984-989

Naldoni J, Adriano EA, Hartigan A, Sayer C, Okamura B (2019) Malacosporean myxozoans exploit a diversity of fish hosts. Parasitology 146:968-978

Okamura B, Hartikainen H, Schmidt-Posthaus H, Wahli T (2011) Life cycle complexity, environmental change and the emerging status of salmonid proliferative kidney disease. Freshw Biol 56:735-753

Okamura B, Gruhl A, Bartholomew JL (2015) An introduction to myxozoan evolution, ecology and development. In: Okamura B, Gruhl A, Bartholomew JL (eds) Myxozoan evolution, ecology and development. Springer International Publishing, Cham, p 1-20

Kokamura B, Hartigan H, Naldoni N (2018) Extensive uncharted biodiversity: the parasite dimension. Integr Comp Biol 58:1132-1145

Opitz S, Rhoten J (2017) 2016 mountain whitefish kill on the Yellowstone River. Montana Fish, Wildlife and Parks, Bozeman, MT

Patra S, Hartigan A, Morris DJ, Kodadkova A, Holzer AS (2017) Description and experimental transmission of Tetracapsuloides vermiformis $\mathrm{n}$. sp. (Cnidaria: Myxozoa) and guidelines for describing malacosporean species including reinstatement of Buddenbrockia bryozoides n. comb. (syn. Tetracapsula bryozoides). Parasitology 144: 497-511

Schröder O (1910) Buddenbrockia plumatellae, eine neue
Mesozoenart aus Plirmatella repens L. und PI. fungosa Pall. Z Wiss Zool 96:525-537

Sobociński B, Huusko A, Vasemägi A (2018) First record of Tetracapsuloides bryosalmonae (Myxozoa; Malacosporea) in European whitefish (Coregonus lavaretus). Bull Eur Assoc Fish Pathol 38:171-176

S Sterud E, Forseth T, Ugedal O, Poppe TT and others (2007) Severe mortality in wild Atlantic salmon Salmo salar due to proliferative kidney disease (PKD) caused by Tetracapsuloides bryosalmonae (Myxozoa). Dis Aquat Org 77 : 191-198

Tops S (2004) Ecology, life history and diversity of malacosporeans. PhD dissertation, University of Reading

Tops S, Lockwood W, Okamura B (2006) Temperaturedriven proliferation of Tetracapsuloides bryosalmonae in bryozoan hosts portends salmonid declines. Dis Aquat Org 70:227-236

Tops S, Hartikainen H, Okamura B (2009) The effects of infection by Tetracapsuloides bryosalmonae (Myxozoa) and temperature on Fredericella sultana (Bryozoa). Int J Parasitol 39:1003-1010

Truett GE, Heeger P, Mynatt RL, Truett AA, Walker JA, Warman ML (2000) Preparation of PCR-quality mouse genomic DNA with hot sodium hydroxide and Tris (HotSHOT). Biotechniques 29:52-54

*Untergasser A, Cutcutache I, Koressaar T, Ye J, Faircloth BC, Remm M, Rozen SG (2012) Primer3-new capabilities and interfaces. Nucleic Acids Res 40:e115

* Vasemägi A, Nousiainen I, Saura A, Vähä JP, Valjus J, Huusko A (2017) First record of proliferative kidney disease agent Tetracapsuloides bryosalmonae in wild brown trout and European grayling in Finland. Dis Aquat Org 125:73-78

*Vesterlund SR, Sorvari J, Vasemägi A (2014) Molecular identification of cryptic bumblebee species from degraded samples using PCR-RFLP approach. Mol Ecol Resour 14:122-126

Appendix. Restriction enzyme reaction protocol

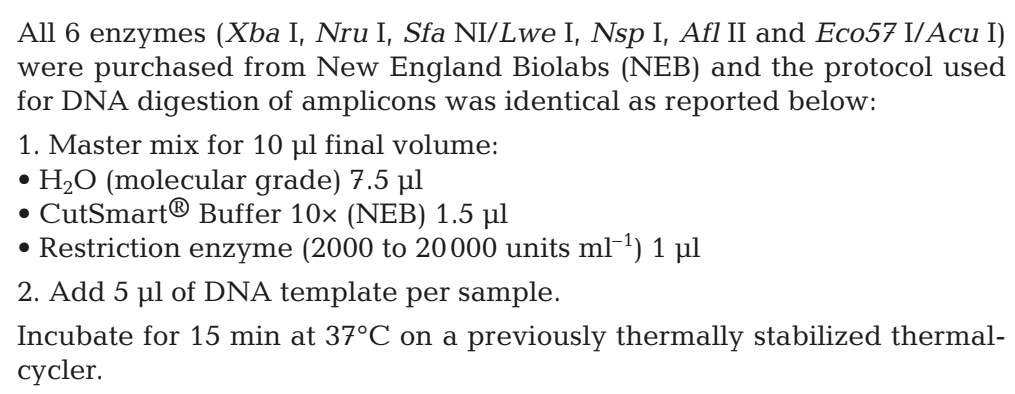

All 6 enzymes (Xba I, Nru I, Sfa NI/Lwe I, Nsp I, Afl II and Eco57 I/Acu I) were purchased from New England Biolabs (NEB) and the protocol used for DNA digestion of amplicons was identical as reported below:

1. Master mix for $10 \mu$ final volume:

- $\mathrm{H}_{2} \mathrm{O}$ (molecular grade) $7.5 \mu \mathrm{l}$

- CutSmart ${ }^{\circledR}$ Buffer 10× (NEB) $1.5 \mu \mathrm{l}$

- Restriction enzyme (2000 to 20000 units $\mathrm{ml}^{-1}$ ) $1 \mu \mathrm{l}$

2. Add $5 \mu$ l of DNA template per sample.

Incubate for $15 \mathrm{~min}$ at $37^{\circ} \mathrm{C}$ on a previously thermally stabilized thermalcycler.

Editorial responsibility: Catherine Collins, Jouy-en-Josas, France
Submitted: February 24, 2020; Accepted: August 7, 2020 Proofs received from author(s): September 11, 2020 